\title{
Widespread Development of Silcrete in the Cretaceous and Evolution of the Poaceae Family of Grass Plants
}

\author{
Timothy Bata ${ }^{1,2}$ \\ ${ }^{1}$ Department of Geology and Petroleum Geology, University of Aberdeen, Aberdeen UK \\ ${ }^{2}$ Department of Applied Geology, Abubakar Tafawa Balewa University, Bauchi, Nigeria \\ Correspondence: Timothy Bata, Department of Geology and Petroleum Geology, University of Aberdeen, \\ Aberdeen UK. Tel: 4474-2593-4972. E-mail: timothybata@abdn.ac.uk/timothybata@icloud.com \\ Received: February 11, 2016 \\ Accepted: March 8, 2016 \\ Online Published: March 24, 2016 \\ doi:10.5539/esr.v5n2p1 \\ URL: http://dx.doi.org/10.5539/esr.v5n2p1
}

\begin{abstract}
The Cretaceous period, which is considered one of the most remarkable periods in Earth's history, saw episodes of abrupt greenhouse warming and cooling. The Cretaceous was also exceptional in that it was associated with the widespread occurrence of silcrete. To demonstrate this, the present study collated records of silcrete occurrences from the Jurassic to the present and compared them with records of variation in palaeotemperature and atmospheric $\mathrm{CO}_{2}$ levels. Quartz solubility, which is one of the key factors that controls the rate of silcrete development, was also calculated over the same period. The results demonstrate that a marked increase (approximately 100\%) in quartz solubility occurred during the Cretaceous. This was found to be a direct consequence of the extreme global warmth witnessed at that time. Furthermore, this study shows that silcrete occurrences are consistent with records of palaeotemperature and that silcretes have formed mostly in regions that have experienced warm climatic conditions, with no instances found in polar regions. The Poaceae family of grass plants are known to have evolved and diversified during the Cretaceous, which coincide with the period when silica was readily available. X-ray spectra and backscattered images from SEM examination of the internal structure of a modern wild grass (which belongs to the Poaceae family of grass plants) reveals that silica is an important constituent of the grass. This suggest a possible link between evolution of the Poaceae family in the Cretaceous and the high availability of silica during the Cretaceous.
\end{abstract}

Keywords: silcretes, palaeogeography, quartz solubility, cretaceous greenhouse climate, poaceae family of grass plants

\section{Introduction}

\subsection{Introduction: Origin of Silcrete}

The Cretaceous period is considered as one of the most remarkable periods in Earth's history, because of the greenhouse climatic condition that prevailed globally at that time. The Cretaceous was also exceptional in that it was associated with the widespread occurrence of silcrete. The purpose of this study is to highlight the anomalous development of silcrete during the Cretaceous by collating records of silcrete occurrences from the Jurassic to the present and comparing them with records of variation in global atmospheric $\mathrm{CO}_{2}$ levels, temperature and quartz solubility.

Silcretes are products of silica accumulation formed as a result of the cementation or replacement of surficial materials such as rocks, sediments, or soils by silica. In a chemical weathering environment (such as that of the Cretaceous), silica is released by the chemical weathering of silicate minerals and is transported to the site of silcrete development by either wind and/or water. The development of silcretes usually involves the precipitation and/or crystallisation of silica, probably over long periods of comparative landscape stability, during which only slow geomorphological and chemical changes take place (Hutton et al., 1972; Hutton et al., 1978). Weathering of silicate minerals provides most of the silica needed for silcrete development, with only a small proportion coming from the direct dissolution of quartz, except under intense leaching conditions (Nash and Ullyout, 2007). Rocks rich in ferromagnesian minerals and feldspars also readily release silica as they weather, despite their relatively low silica mineral contents. Furthermore, volcanic ashes containing silicate glass are susceptible to rapid weathering, thereby releasing silica that can accumulate to form silcretes (Terry and Evans, 1994). Other important sources of silica include the kaolinisation of feldspars and the diagenesis of clay mineral (Wopfner, 1983). There are also a number of biological silica sources (e.g., grasses, reeds, horsetails palms, and some hardwoods) that concentrate amorphous silica in their tissue, which is readily released upon decay (Gunn and Galloway, 1978; Clarke 2003). Diatoms, which are common in many lacustrine environments, have also been an important source of silica in near-surface environments during the past 50 million years (Knauth, 1994). Diatoms 
extract silica from surface waters during growth, and subsequently release silica upon their death (Du Toit, 1954).

Three categories of silcretes can be distinguished based on their mode of formation: (1) ground water silcretes, which are the products of silica precipitation from ground water; (2) pedogenic silcretes, which form at surface temperatures and are associated with soil weathering, and; (3) hydrothermal silcretes, which are associated with formation waters or basinal brines, and form at higher temperatures than those found in soil (Alexandre et al., 2004). Groundwater silcretes usually develop as irregular lenses near the Earth's surface, but also occur at depths of up to $100 \mathrm{~m}$, sometimes underlying or overlying pedogenic silcretes (Basile-Doelsch et al., 2005; Milnes et al., 1991; Thiry, 1999; Thiry et al., 1995; Thiry and Simon-Coinçon, 1996). Examples of groundwater silcrete have been reported in the Paris Basin, where the silicification of limestone by silica-bearing solutions passing through the karstic system resulted in the formation of cherts (Thiry, 1999). Groundwater silcretes generally lacks an ordered profile and complex micromorphology. Instead, they exhibit simple fabrics with good preservation of host structures (Ullyott and Nash, 2006).

The development of pedogenic silcretes is typically associated with the downward percolation of silica-bearing water in cycles of flushing and precipitation, usually under climatic conditions with high rates of evaporation (Webb and Golding, 1998). Pedogenic silcrete profiles can be further differentiated into two sections: an upper part, which usually exhibits columnar structures with well-ordered silica cements that imply the interplay of dissolution and percolation (Milnes and Thiry, 1992), and a lower section that is usually weakly cemented and poorly ordered. The lower section often has a nodular appearance and is characterised by illuvial deposition (Milnes and Twidale, 1983).

Once silica has been released by weathering, it can be transported over considerable distances by wind and/or water before concentrating to form silcretes. Goudie and Middleton (2001) showed that quartz dust can be transported by wind over a considerable distance in desert environments. Similarly, Clarke (2003) showed that plant phytoliths, sponge spicules, and diatoms can also be subjected to aeolian transportation. Summerfield (1983a) divided the means of silica transport into lateral and vertical transportation mechanisms. Most documented lateral silica transportation involves silica movement within surface and ground water over scales ranging from local to sub-continental (Hutton et al., 1972, 1978; Stephens, 1971). Vertical silica transportation involves the movement of silica-bearing soil or ground water within the vadose zone, either by capillary rise, which is supported by evaporation, or by the mixing of upward migrating solutions (per ascensum) or downward percolating solutions (per descensum) (Smale, 1973).

Silica precipitation can take place in arid, semi-arid, or humid environments, provided there is an abundant supply of water and dissolved silica (Summerfield, 1983b), and more silcretes will form where there is more silica in solution. In any supersaturated silica solution, the most soluble species of silica is precipitated first (Millot, 1960, 1970). This is usually amorphous silica, which is both poorly ordered and has a relatively higher solubility under neutral conditions as compared with opal-C (William et al., 1985). Silica precipitation is influenced by environmental $\mathrm{pH}, \mathrm{eH}$, temperature, pressure, evaporation, life processes, and the presence of other dissolved constituents (Nash and Hopkinson, 2004).

Silica solubility is relatively stable under weakly acidic to neutral pH, but increases rapidly above pH 9 (Dove and Rimstidt, 1994; Lindsay, 1979). Such environmental $\mathrm{pH}$ conditions are common in arid and semi-arid regions where alkaline conditions may occur as a result of evaporation (Chadwick et al., 1989). Furthermore, Nash and Ullyout (2007) showed that the effects of fluctuating temperature and pressure are negligible in near-surface environments as a result of the slow associated rate of change in quartz solubility near the surface. However, temperature plays an important role in silica precipitation as more silica is expected to precipitate from a silica-saturated solution at higher temperatures (e.g., Rimstidt, 1997). The effect of evaporation on silica precipitation is obvious in near-surface environments, most especially in the development of the upper part of pedogenic silcrete profiles in highly evaporitic settings (Milnes et al., 1991; Thiry and Millot, 1987; Webb and Golding, 1988; Wopfner, 1983). There are also documented examples that demonstrate the influence of biological activity on silica precipitation. For example, Shaw et al. (1990) described the role of cyanobacteria in silcrete development in Botswana, while McCarthy and Ellery (1995) showed that transpiration from aquatic grasses has an effect on the precipitation of amorphous silica from groundwater. 


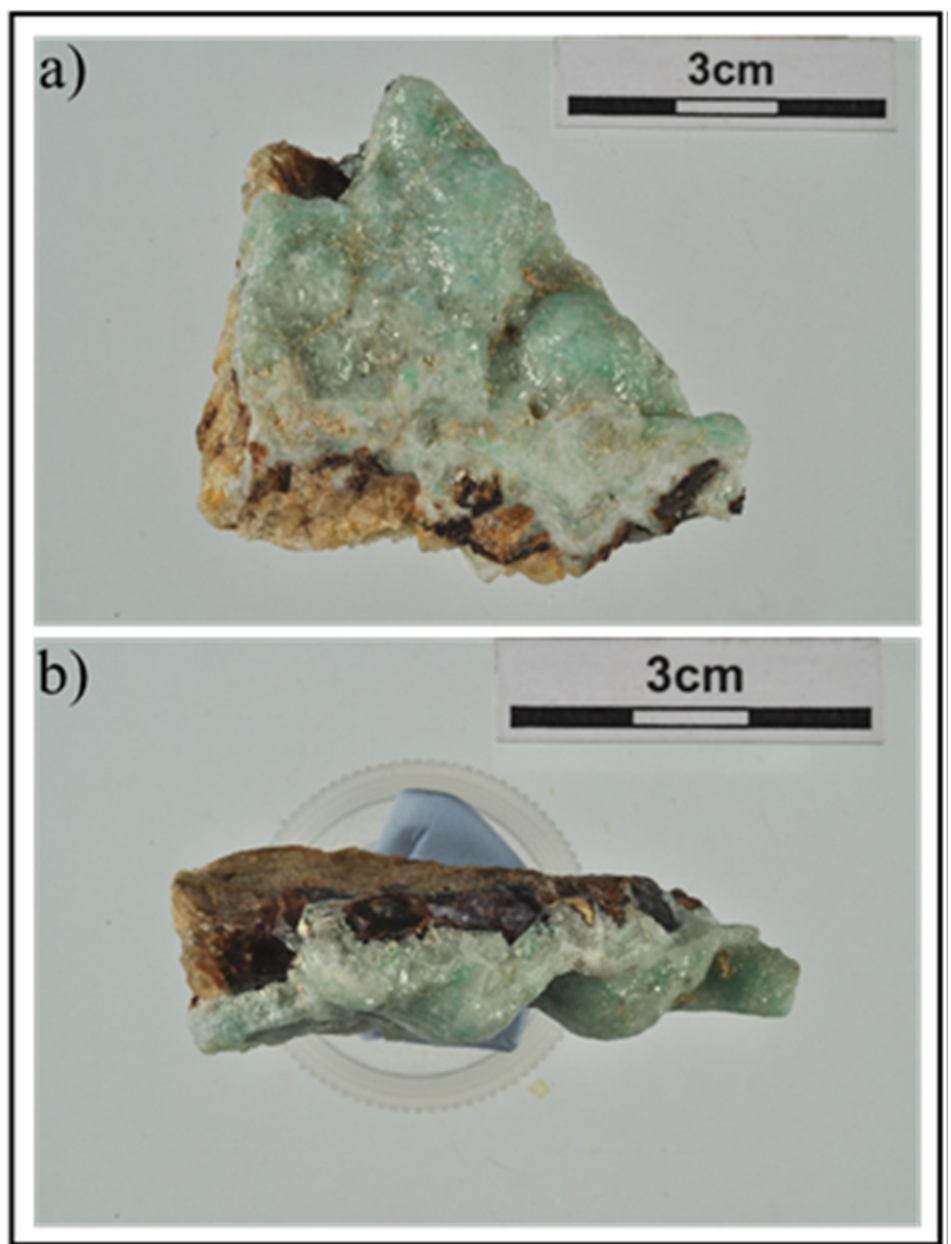

Figure 1. Example of a silcrete obtained from the Blanchard Mine, Socorro County, New Mexico (USA). Note how the fluorite rich silica replaces other mineral grains in the sample

\subsection{General Characteristics of Silcretes}

In general, the morphology of an individual silcrete profile reflects its mode of formation and the nature of its host material (Milnes and Thiry, 1992; Summerfield, 1983a and b). However, silcrete appearances vary even between profiles developed by comparable processes, such that it is can be difficult to distinguish silcrete types on the basis of macromorphology alone. An example of this is the groundwater silcrete profile at Stuart Creek, Australia, which contains amoeboid opalite masses in Cretaceous shale, as well as massive or tuberous bodies within Tertiary fluvial sands (Thiry and Milnes, 1991). Common silcrete colours include grey, white, buff, brown, red, and green, with the accessory minerals influencing the colour (Milnes and Twidale, 1983).

The chemical composition of silcrete is simple, usually comprising $>90 \%$ silica with minor amounts of Ti, Fe, and $\mathrm{Al}$ oxides. Silcrete mineralogy also often reflects the properties of the host material and the conditions under which silica precipitation occurred (Summerfield, 1983a, and b). The detrital components of silcretes are usually quartzose, while the matrix often contains a range of silica species (or polymorphs), of which the most generally recognised are opal, chalcedony, and quartz. Opal usually occurs both within the silcrete matrix and as a cavity lining (Bustillo and Bustillo, 2000), but may also be present as non-crystalline opal-A and opal-AG or in near-amorphous-microcrystalline forms such as opal-T, opal-C, or opal-CT (Flörke et al., 1991).

Chalcedony, which is a microcrystalline fibrous form of silica, forms as an intergrowth with quartz and the silica polymorph moganite, and usually occurs as cement, void lining, or void-fill (Flörke et al., 1984; Nash and Shaw, 1998; Summerfield, 1983). Quartz in silcretes are usually present within the matrix as microquartz or as well-developed crystals of authigenic $\alpha$-quartz (or megaquartz). Microquartz (grain size $<20 \mu \mathrm{m}$ ) occurs both as a cement and as void-lining, whilst megaquartz $(>20 \mu \mathrm{m})$ generally occurs as intergrown microscopic grains, overgrowths, and as subhedral quartz crystals towards the centre of cavities (Nash and Hopkinson, 2004). A variety of other elements and minerals may also be present in silcretes. For example, Ti is usually present as anatase and may be disseminated throughout opaline cements or concentrated within illuvial features (Thiry, 
1978). Some silcretes are also enriched in $\mathrm{TiO}_{2}$ (Summerfield, 1983b; Thiry and Millot, 1987), which is usually related to host-material chemistry and the ratio of matrix to detrital grains, as well as to the environment of silicification (Nash et al., 1994; Webb and Golding, 1998).

\subsection{Silcretes As Climatic Indicators}

The development of silcrete depends upon a complex interplay between climate and silica supply (Nash and Ullyout, 2007). Early studies on silcretes (e.g., Stephens 1971; Summerfield, 1983b), suggests that silcretes developed in arid and semi-arid environments. Silcretes have generally been considered as indicators of warm humid climatic conditions (Hutton et al., 1978; Nash and Ullyout, 2007; Twidale et al., 1976; Twidale and Hutton, 1986). In the absence of precise dating, some specific Cenozoic silcretes have been related to the warm humid climatic conditions that prevailed during their formation (e.g., Summerfield, 1983a). Silcretes have also been considered as the products of long periods of weathering, usually associated with warm humid climatic conditions (Twidale \& Hutton, 1986), as inferred from palaeontological evidence (e.g., Hutton et al., 1978; Kemp, 1978; Wopfner, 1978). For example, stratigraphic evidence from the silcrete profile of the lower Lake Eyre Basin, Australia, suggests evolution during the Late Cretaceous and early Miocene, when the region enjoyed a warm, humid climatic condition (Hutton et al., 1978).

There are challenges in dating silcrete occurrences. These challenges occur due to the impacts of paragenesis and the possibility of having multiphase cement occurrences in silcrete profiles (e.g. Twidale, 2002). Most silcrete studies, however, use relative dating approaches, where the ages of silcretes are determined from their stratigraphic position. This concept has been efficiently employed in France (e.g. Thiry, 1999), and in Australia, where the occurrence of plant fossils and basalts of known ages have been used to age-constrain silcrete deposits (e.g., Taylor and Eggleton, 2001).

In general, temperature plays an important role in silcrete development as it controls the solubility of silica in solution (quartz solubility), which in turn controls the availability of silica for silcrete development. Rimstidt (1997) suggested a mathematical relationship between temperature and quartz solubility for temperatures ranging between $0^{\circ} \mathrm{C}$ and $300^{\circ} \mathrm{C}$. This mathematical function states that:

$\log \mathrm{m}=-1107.12( \pm 10.77) / \mathrm{T}-0.0254( \pm 0.0247)$.

Where $m$ is the molal solubility and $T$ is measured in Kelvins.

According to this mathematical function, the solubility of silica increases with increasing temperature. For example, the solubility of silica at $5^{\circ} \mathrm{C}$ is $6.0 \pm 1.1 \mathrm{ppm}$, and at $25^{\circ} \mathrm{C}$ it is $11.0 \pm 1.1$. This relationship between temperature and quartz solubility implies that more silica is expected to be removed from soils and rock profiles at relatively higher temperatures than at lower temperatures. Therefore, warm and humid climatic conditions (such as was experienced globally in the Cretaceous) should allow for more silcrete development than in cold climates.

\subsection{Silcretes in the Geologic Record}

Silcrete occurrences have been documented on all continents except Antarctica (Nash and Ullyout, 2007). Silcretes are most widespread in Australia and in the Kalahari and Cape coastal areas of southern Africa. Based on their distribution, the prerequisites for silcrete development appear to include sub-aerial weathering under temperate-tropical climatic conditions. There is evidence in the geological record (e.g., Peters and Gaines, 2012) to show that the Neoproterozoic was associated with widespread continental denudation, and Neoproterozoic erosional surfaces that reflect prolonged sub-aerial weathering under temperate-tropical climatic conditions occur in several places worldwide.

As silica translocation is a common occurrence in sub-aerial weathering profiles (Smith et al., 1997), some Precambrian unconformities are also associated with silcretes. Such examples include the silcrete profiles along the south-eastern margin of the Australian Precambrian Shield (Firman, 1994). Other examples of silcretes associated with unconformities include the Proterozoic silcretes of the Bear and Churchill provinces of the north-western Canadian Shield (Ross and Chiarenzelli, 1985), and the silcretes within outcrops surrounding the Wisconsin Arch, USA (Smith et al., 1997). Silcrete deposits from other geologic periods are also found in the geological record, and their formation can also be linked with evidence of temperate-tropical climatic conditions. Examples include the silcretes associated with the Pennsylvanian-Permian Belloy Formation of the Peace River Embayment, West Central Alberta, Canada (Moore and Henderson, 1998), and those associated with the Devonian Old Red Sandstone of the Orcadian Basin, Scotland (Parnell, 1983).

\section{Method}

Records of silcrete occurrences from the Jurassic to the present day were compiled with respect to their stratigraphic positions. The search was carried out using online search engines for the Jurassic, the Cretaceous and the Cenozoic. Records of variations in the global atmospheric level of carbon dioxide, temperature, sea level and average area of land available to weathering were also compiled for the same geologic periods to 
demonstrate how they relate to the occurrences of silcretes. Using the mathematical relationship:

$\log \mathrm{m}=-1107.12( \pm 10.77) / \mathrm{T}-0.0254( \pm 0.0247)$,

Which was determined by Rimstidt (1997), quartz solubility was calculated for the different mean surface temperatures witnessed during the Jurassic, the Cretaceous and the Cenozoic. Reconstructed world palaeogeographic maps after Blakey (2011) were used to plot the palaeolatitude distribution of the silcretes. Leaves of modern day wild grass (which also belongs to the Poaceae family of grass) were collected, dried, carbon coated and and examined using an ISI ABT-55 scanning electron microscope (SEM) with Link Analytical 10/55S EDAX facility for the occurrence of silica in the leaves. This is based on the assertion that the Poaceae family of grass plants evolved and diversified during the Cretaceous as it is documented in the biogeological records (e.g., Bouchenak-Khelladi et al., 2010; Bremer 2002; Jassen and Bremer 2004; Kellogg, 2010). X-ray spectra and backscattered images were obtained from the SEM.

\section{Results and Discussion}

\subsection{Jurassic to Cenozoic Silcrete Deposits}

The global Cretaceous weathering events were attributed to the warm humid climatic condition that prevailed globally at that time. This further implies that the general climatic condition during the Cretaceous was suitable for the release of large volumes of silica from Cretaceous rock profiles and soils. In order to explore this hypothesis, records of silcrete occurrences from the Jurassic to the Cenozoic will be presented and discussed in the ensuing section. This is aimed at demonstrating the effect of the extreme global warmth, witnessed in the Cretaceous, on silcrete development.

Palaeogeographic studies have shown that the continents were previously sutured together in a single continent called Pangaea, which existed during the Early Jurassic (e.g., Blakey, 2011; Golonka, 2007; Scotese, 2001), a time of low mean global surface temperature $\left(\sim 5^{\circ} \mathrm{C}\right.$; e.g., Veizer et al., 2000). Based on the mathematical relationship between temperature and quartz solubility (Rimstidt, 1997), a temperature of $5^{\circ} \mathrm{C}$ implies a low quartz solubility of just $6 \mathrm{ppm}$, which explains why very few Early Jurassic silcrete deposits are documented in the geological record (Table 4.1; Fig. 2). However, an example of an Early Jurassic silcrete profile occurs at the Limpopo Valley of Zimbabwe (Terry et al., 2001). During the Early Jurassic, Zimbabwe is estimated to have been at a palaeolatitude of $30^{\circ} \mathrm{S}$ (Fig. 2) and it is presumed that warm climatic condition prevailed (e.g., Bordy and Catuneanu, 2002), despite the generally low global surface temperature.

The Earth became warmer towards the end of the Jurassic, in response to a rise in atmospheric $\mathrm{CO} 2$ caused by volcanic activity associated with the breakup of Pangaea. In particular, the mean global surface temperature rose to $\sim 7^{\circ} \mathrm{C}$ during the Late Jurassic, corresponding to an increase in quartz solubility. Compared with the Early Jurassic, relatively more silcretes developed in the Late Jurassic in response to the rising global temperature. Late Jurassic silcretes have been reported in Australia, South Africa, France, Canada and Brazil (Al-Ramadan et al., 2005; Du Toit and Reed 1954; Krausse and Mello, 2010; Laity, 2009; Pierini et al., 2010; Twidale and Campbell, 1995; Wopfner, 1978).

Table 1. Record of Jurassic Silcretes

\begin{tabular}{|c|c|c|c|c|}
\hline S/No & Country & Locality & $\begin{array}{l}\text { Age of } \\
\text { Silcrete }\end{array}$ & Reference \\
\hline 1 & Zimbabwe & $\begin{array}{l}\text { Limpopo } \\
\text { Zimbabwe }\end{array}$ & Hettangian & Terry et al., 2001 \\
\hline 2 & Australia & Lake Eyre, Queensland & Tithonian & Laity, 2009 \\
\hline 3 & Australia & Lake Eyre, Queensland & Tithonian & Wopfner, 1978; Twidale and Campbell, 1995 \\
\hline 4 & $\begin{array}{l}\text { South } \\
\text { Africa }\end{array}$ & Tuli Basin & Tithonian & Du Toit and Reed 1954 \\
\hline 5 & France & Boulonnais & Titthonian & Al-Ramadan et al., 2005 \\
\hline 6 & Canada & West-central Alberta & Tithonian & Krausse and Mello, 2010 \\
\hline 7 & Brazil & Reconcavo Basin & $\begin{array}{l}\text { Kimmeridg } \\
\text { ian }\end{array}$ & Pierini et al., 2010 \\
\hline
\end{tabular}




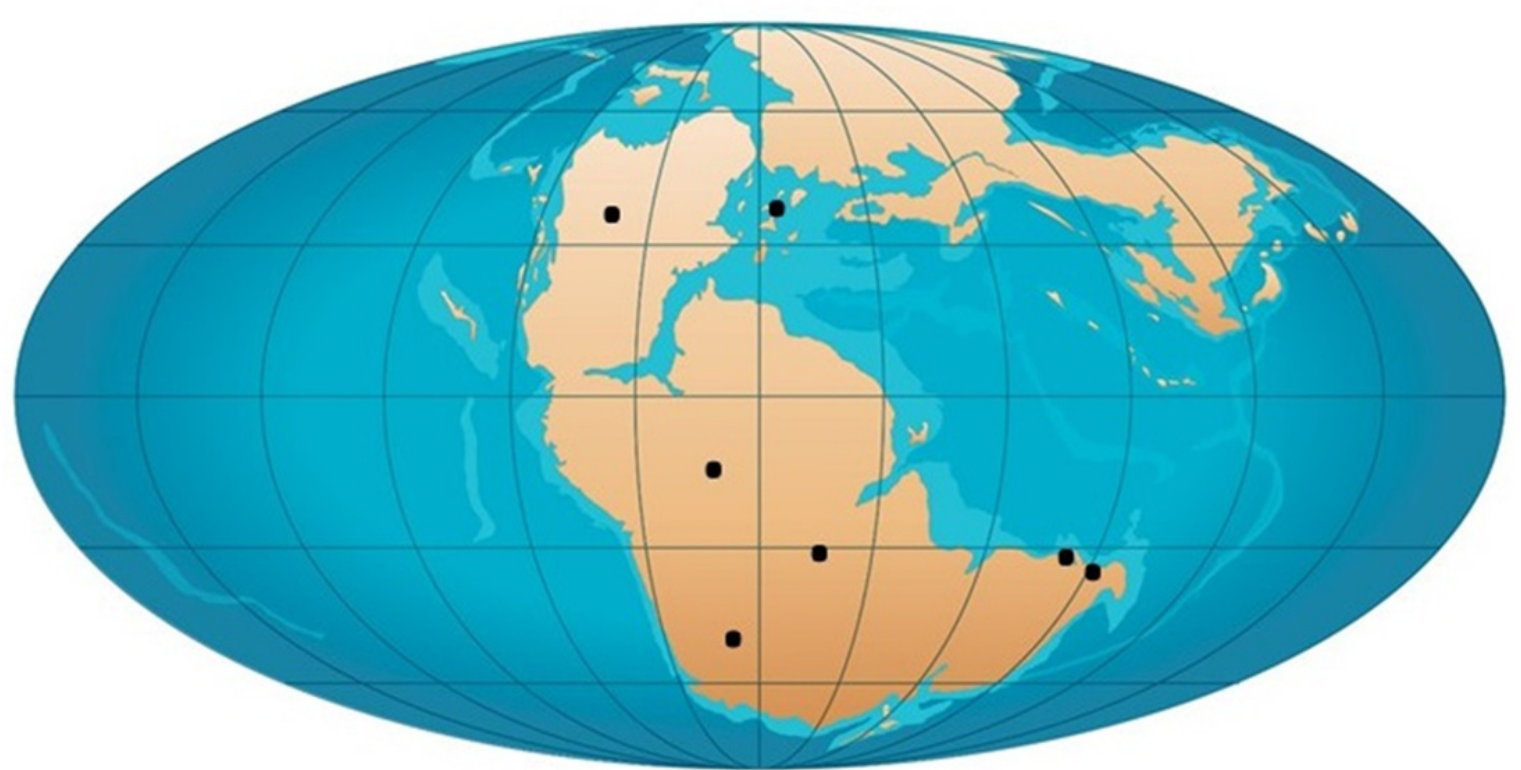

Figure 2. Reconstructed Jurassic palaeogeographic world map (modified from Blakey, 2011), showing the approximate locations of Jurassic silcretes, which are concentrated within Gondwana

The Earth continued to warm during the Cretaceous, with average global surface temperature peaking at $\sim 28^{\circ} \mathrm{C}$ in the mid-Cretaceous (Scotese, 2001; Skelton, 2003; Veizer et al., 2000; Wang et al., 2014; Bata et al., 2015). This resulted in a dramatic increase (of $\sim 100 \%$ ) in quartz solubility (from $\sim 6 \mathrm{ppm}$ in the Early Jurassic to $\sim 12$ ppm by the mid-Cretaceous). This high quartz solubility is consistent with the abundance of Cretaceous silcretes in the geological record (Table 2; Fig. 3). Cretaceous silcretes have been reported at high palaeolatitudes, for example, the silcrete profile of west-central Alberta, Canada (Krausse and Mello, 2010 which was estimated to have been at palaeolatitude $58^{\circ} \mathrm{N}$ in the Cretaceous (Fig. 2). Similarly, Cretaceous silcretes have been reported in the Andean Basin, Argentina (Sempéré et al., 1997) and Grahamstown, South Africa (Jacob et al., 2004). Argentina and South Africa were estimated to have extended to palaeolatitude of about $50^{\circ} \mathrm{S}$ in the Cretaceous (Fig. 3).

Table 2 Record of Cretaceous Silcretes.

\begin{tabular}{|c|c|c|c|c|}
\hline S/No & Country & Locality & Age of Silcrete & Reference \\
\hline 1 & Australia & Eromanga Basin & Barremian & Alley et al., 1996 \\
\hline 2 & France & South-east France & Albian & Alexandre et al., 2006 \\
\hline 3 & Canada & West-central Alberta & Berriasian & Krausse and Mello, 2010 \\
\hline 4 & Thailand & North-eastern Thailand & Barremian & Meesook, 2000 \\
\hline 5 & Thailand & Khorat Plateau & Berriasian & Meesook, 2000 \\
\hline 6 & Israel & $\begin{array}{l}\text { Tethys Shoreline, Makhtesh } \\
\text { Gadol }\end{array}$ & Berriasian & Azmon and Kedar, 1985 \\
\hline 7 & Timor & Eastern Timor & Albian & Audley-Charles, 1965 \\
\hline 8 & Greece & Greece & Berriasian & Valeton et al., 1987 \\
\hline 9 & USA & North Texas & Berriasian & Murray, 1990 \\
\hline 10 & USA & Colorado Plateau & Aptian & Aubrey, 1998 \\
\hline 11 & India & Narmada Rift Basin & Albian & Akhtar et al., 1992 \\
\hline 12 & Yemen & Masila Region & Aptian & Putnam et al., 1997 \\
\hline 13 & Brazil & Parana Basin & Berriasian & Scherer and Lavina, 2006 \\
\hline 14 & Spain & Duero Basin & Albian & Blanco et al., 2008 \\
\hline 15 & Slovakia & Western Carpathians & Berriasian & Misik, 1996 \\
\hline 16 & Australia & Darwin-Kopinya & Maastrichtian & Borger et al., 2004 \\
\hline 17 & Australia & $\begin{array}{l}\text { Eromanga, } \\
\text { Basin, Queensland }\end{array}$ & Maastrichtian & Idnurm and Senior, 1977 \\
\hline 18 & Australia & Lower Lake Eyre Basin & lower Lake Eyre & Hutton et al., 1978 \\
\hline
\end{tabular}




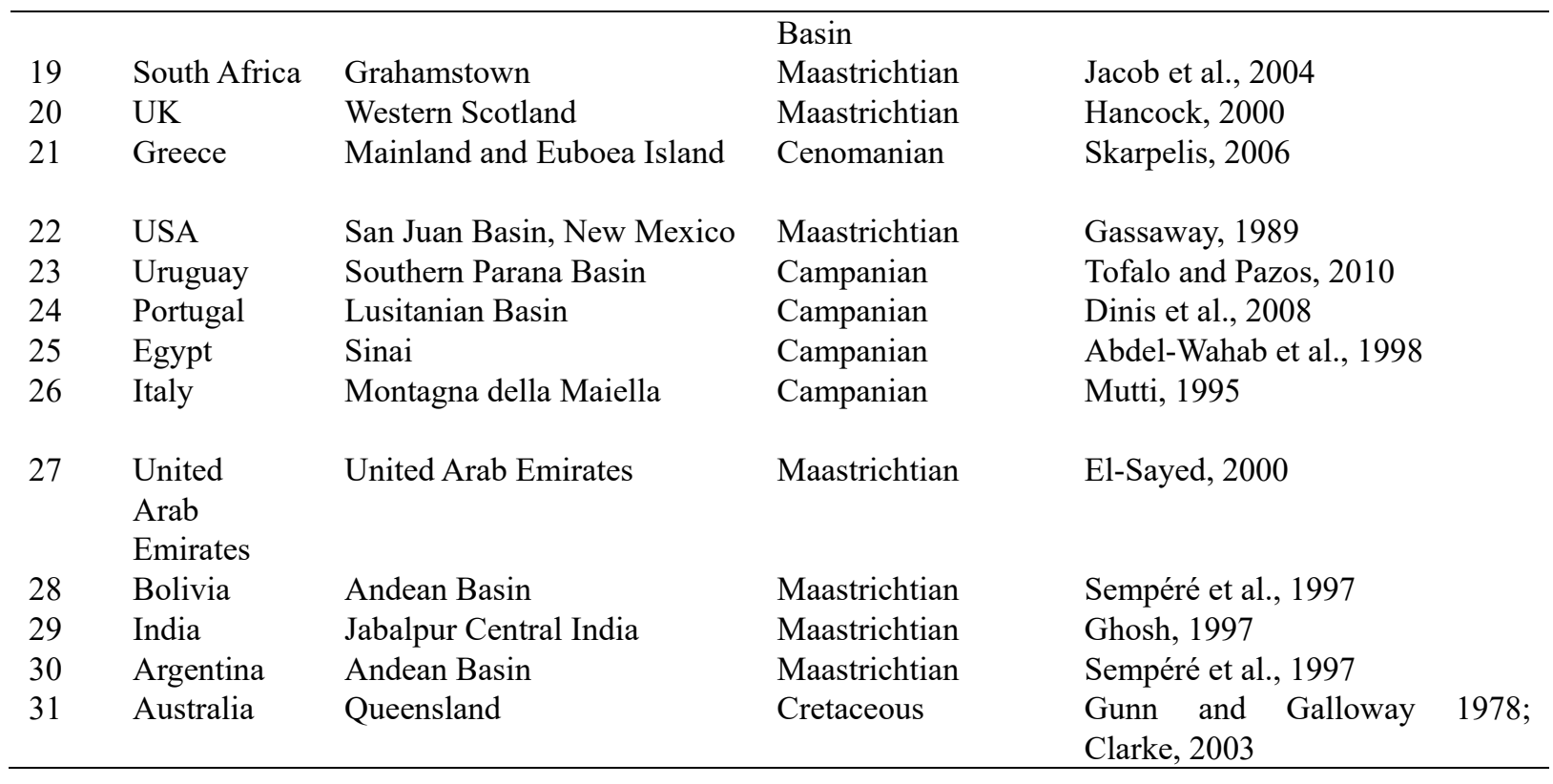

The formation of Cretaceous silcretes at such high palaeolatitudes suggests an upward warming trend, consistent with palaeotemperature estimates for the early Cretaceous (e.g., Huber et al., 1995, 2002; Friedrich et al., 2012). Apart from their widespread occurrence, which is anomalous, Cretaceous silcretes are no different from those formed during other geologic ages in terms of morphology and chemical composition. There is documented evidence in the geological record for both pedogenic and groundwater silicification during the Cretaceous. Evidence of Cretaceous groundwater silicification includes the superposition of several silcrete horizons, preservation of structures from the host rocks, scarce areal extent of some deposits, the formation of massive silcrete lenses in some places, complex pore infilling, nodular horizons, lack of columnar top structures, and the replacement of clay minerals (Thiry and Simon-Coincon, 1996; Tofalo and Pazos, 2010; Ullyott and Nash, 2006). Pedogenetic features associated with some of the Cretaceous silcretes include clay deposits in soil channels, peds and microfracture sets, root structures, animal burrows, and abundant nodular/disseminated Fe sulphides (Krause and Mellor, 2010).

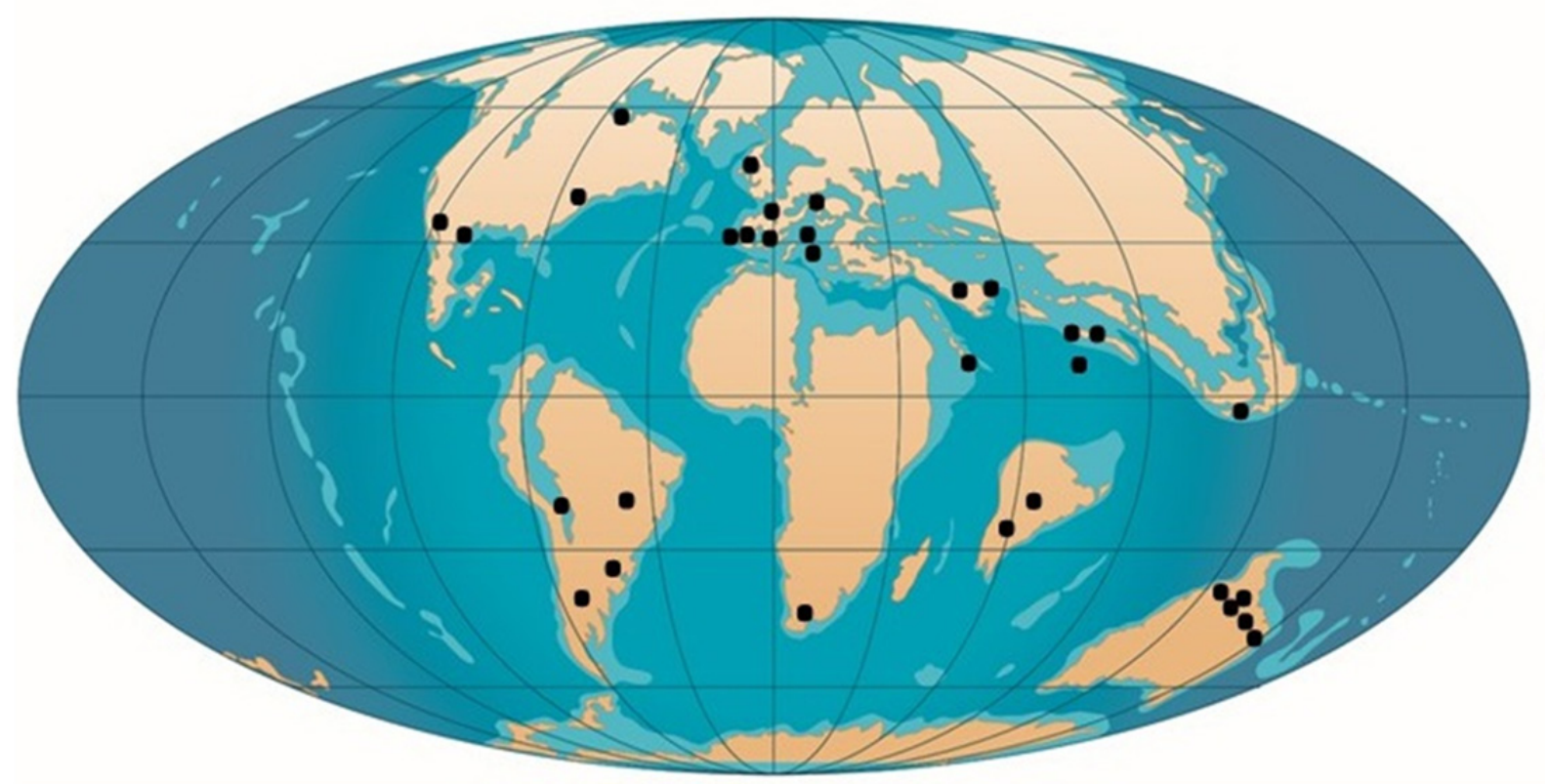

Figure 3. Reconstructed Cretaceous palaeogeographic world map (modified from Blakey, 2011), showing the approximate locations of Cretaceous silcretes. Note the widespread occurrence of Cretaceous silcretes 
The Earth's temperature dropped at the end of the Cretaceous period, possibly as a result of the intense global weathering, which is known to draw down $\mathrm{CO}_{2}$ from the atmosphere as periods of intense weathering are usually followed by periods of cooling (Berner, 1992; Kump et al., 2005; Godie and Viles, 2010). The widespread intense weathering witnessed in the Cretaceous must have removed significant amount of $\mathrm{CO}_{2}$ from the atmosphere, resulting in a drop in global temperatures. This drop also resulted in a corresponding drop in quartz solubility in the early Cenozoic, evident by the relatively fewer occurrence of Cenozoic silcretes with most of the Cenozoic silcretes concentrated in Australia where a warm humid climate prevails at present (Table 3; Fig. 4).

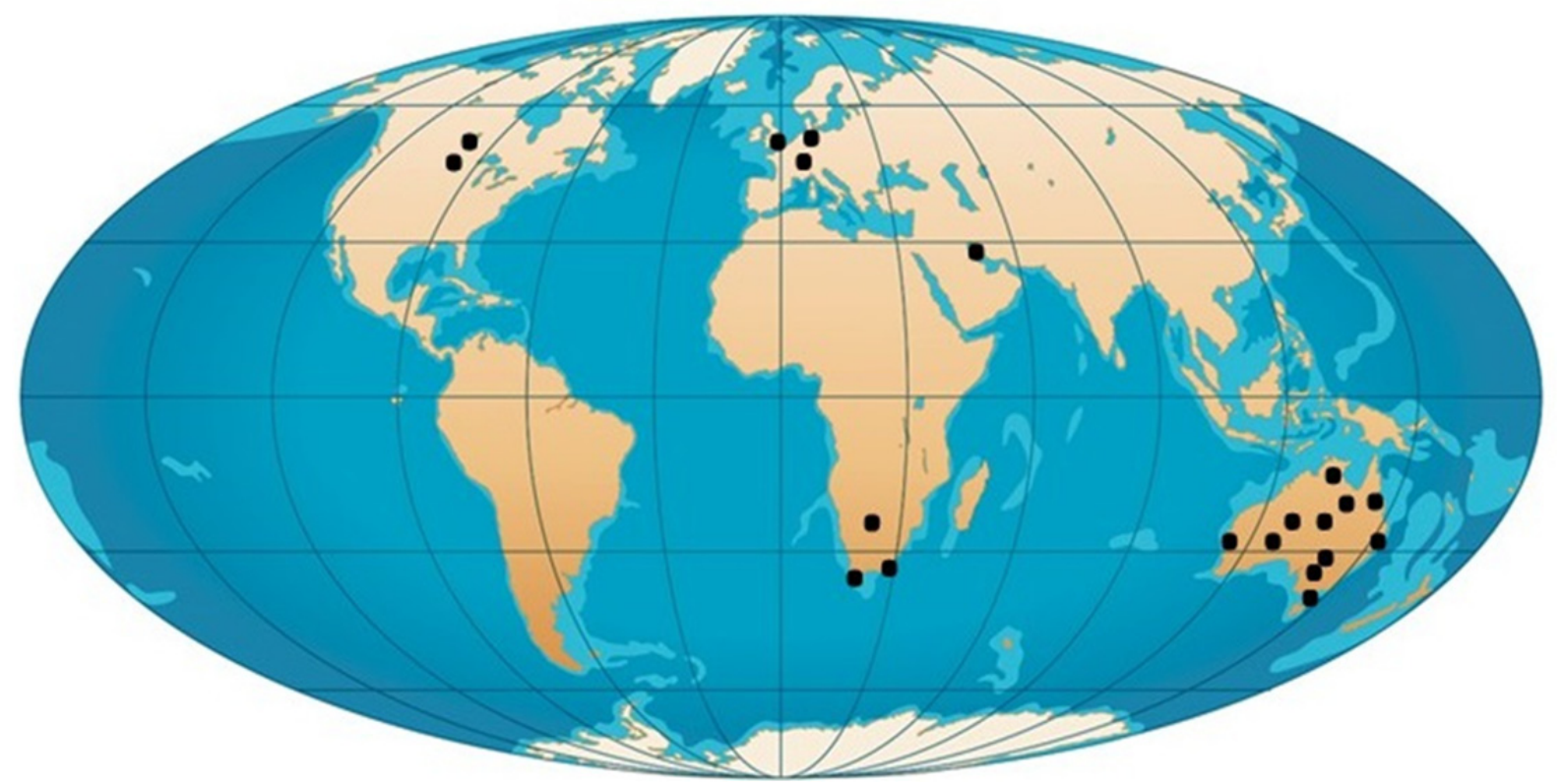

Figure 4. Present-day palaeogeographic world map (modified from Blakey, 2011), showing the approximate locations of Cenozoic silcretes, which are mostly located in Australia and southern Africa, with some in Europe and southern Kuwait

Table 3 Record of Cenozoic Silcretes

\begin{tabular}{|c|c|c|c|c|}
\hline S/No & Country & Locality & Age of Silcrete & Reference \\
\hline 1 & Australia & New South Wales & Holocene & Glen and Hutton, 1983 \\
\hline 2 & Australia & Queensland & Pleistocene & Radtke and Brückner, 1991 \\
\hline 3 & Australia & $\begin{array}{l}\text { Lake Eyre } \\
\text { Queensland }\end{array}$ & Miocene & $\begin{array}{l}\text { Hutton et al., 1978; Alexandre et al., } \\
2004\end{array}$ \\
\hline 4 & Australia & West Australia & Miocene & Twidale, 2007 \\
\hline 5 & Australia & West Australia & Eocene & Twidale, 2007 \\
\hline 6 & Australia & South Australia & Miocene & $\begin{array}{l}\text { Hutton et al., 1972; Smale, 1973; } \\
\text { Twidale, } 2007\end{array}$ \\
\hline 7 & Australia & North Australia & Eocene & Twidale, 2007 \\
\hline 8 & Australia & Central Victoria & Miocene-Pliocene & Webb and Golding, 1988 \\
\hline 9 & Australia & $\begin{array}{l}\text { Central and Southern } \\
\text { Australia }\end{array}$ & Tertiary & Milnes and Twidale, 1983 \\
\hline 10 & Australia & Northern-South Australia & Cenozoic & Milnes et al., 1991 \\
\hline 11 & Australia & Inland Australia & Tertiary & Thiry et al., 1995 \\
\hline 12 & USA & Dakota & Eocene & Terry and Evans, 1994 \\
\hline 13 & $\begin{array}{l}\text { South } \\
\text { Africa }\end{array}$ & Southern Cape Province & Holocene & Stephens, 1971; Summerfield, 1983b \\
\hline 14 & $\begin{array}{l}\text { South } \\
\text { Africa }\end{array}$ & Western South Africa & Palaeocene & De Wit, 1999 \\
\hline 15 & France & Southern Paris & Pleistocene & Thiry and Simon-Coincon, 1996; Thiry, \\
\hline
\end{tabular}




\begin{tabular}{|c|c|c|c|c|}
\hline & & & & 1999 \\
\hline 16 & Canada & Southern Saskatchewan & Miocene & Leckie and Cheel, 1990 \\
\hline 17 & Botswana & Kalahari & Pliocene & Nash et al., 1998 \\
\hline 18 & UK & $\begin{array}{l}\text { Eastern South Downs, } \\
\text { Sussex }\end{array}$ & Pleistocene & Ullyott and Nash, 2006 \\
\hline 19 & Germany & Cologne Embayment & Pleistocene & Wopfner, 1978, 1983 \\
\hline 20 & Kuwait & Southern Kuwait & Mio-Pleistocene & Khalaf, 1988 \\
\hline
\end{tabular}

\subsection{Palaeogeographic Distribution of Jurassic to Cenozoic Silcretes}

It is generally recognised that palaeo- $\mathrm{CO}_{2}$ was the primary driver of the Phanerozoic climate. This is backed by evidence from the geological record, which shows that global temperatures co-varied with atmospheric $\mathrm{CO}_{2}$ during the Phanerozoic (Fig. 5A and 5B; e.g., Goddéris et al., 2014; Royer, 2008, 2010; Royer et al., 2004; Wang et al., 2014). The broad picture of climate and $\mathrm{CO}_{2}$ variation shows that warming trends through the Phanerozoic were accompanied by increasing $\mathrm{CO}_{2}$ levels, while cooler periods were associated with reductions in atmospheric $\mathrm{CO}_{2}$ (Retallack 2001).

During the Mesozoic, and especially the Cretaceous, global temperatures were considerably higher than the present. The Cretaceous global warmth has largely been attributed to elevated levels of atmospheric $\mathrm{CO}_{2}(\mathrm{Barron}$ and Washington, 1985; Berner, 1991). This increase in atmospheric $\mathrm{CO}_{2}$ was caused by volcanic activity associated with fragmentation of the former continents during the Cretaceous (Larson, 1991). Furthermore, the high level of atmospheric $\mathrm{CO}_{2}$ witnessed during the Cretaceous also implies low environmental $\mathrm{pH}$ (e.g., Nikinmaa, 2013), which further suggests that the rate of global chemical weathering was high in the Cretaceous, consistent with data presented in section 3.4 of Chapter Three.

Dating silcrete development is controversial and past works have shown that very few ages of silicification are well constrained (e.g., Thiry et al., 1988). However, in this study a simple dating approach was used, and the ages of silcretes were determined from their stratigraphic position. A good match was observed between the widespread occurrence of Cretaceous silcretes, and the relatively higher surface temperature witnessed globally in the Cretaceous (Fig. 5). This strongly implies that temperature plays a very important role in silcrete development. In fact, the remarkable increase of $\sim 100 \%$ in quartz solubility which occurred between the Jurassic and the Cretaceous (Fig. 5B) is a direct consequence of the rise in global temperature at that time.

Based on the data presented in Figure 5, mean global quartz solubility was 6 ppm during the Jurassic, $8.14 \mathrm{ppm}$ in the Lower Cretaceous, and $10.7 \mathrm{ppm}$ in the Upper Cretaceous. Mean global quartz solubility for the Cenozoic is $8.22 \mathrm{ppm}$. This again demonstrate the relatively higher availability of silica during the Cretaceous, than the Jurassic or Cenozoic. The anomalously high Cretaceous quartz solubility is consistent with the relatively numerous and widespread Cretaceous silcretes, as compared with the Jurassic and the Cenozoic (Fig. 5C).

The formation of Cretaceous silcretes at relatively higher palaeolatitudes than the Jurassic and Cenozoic silcretes is consistent with the greenhouse climatic conditions that resulted in climatic warnings even at high latitudes (Fig. 5). However, no silcrete occurrences have been reported from the polar regions, even during the Cretaceous, because temperatures in these regions have always been low, even without the polar ice, as was the case during the Cretaceous (Scotese, 2001). 


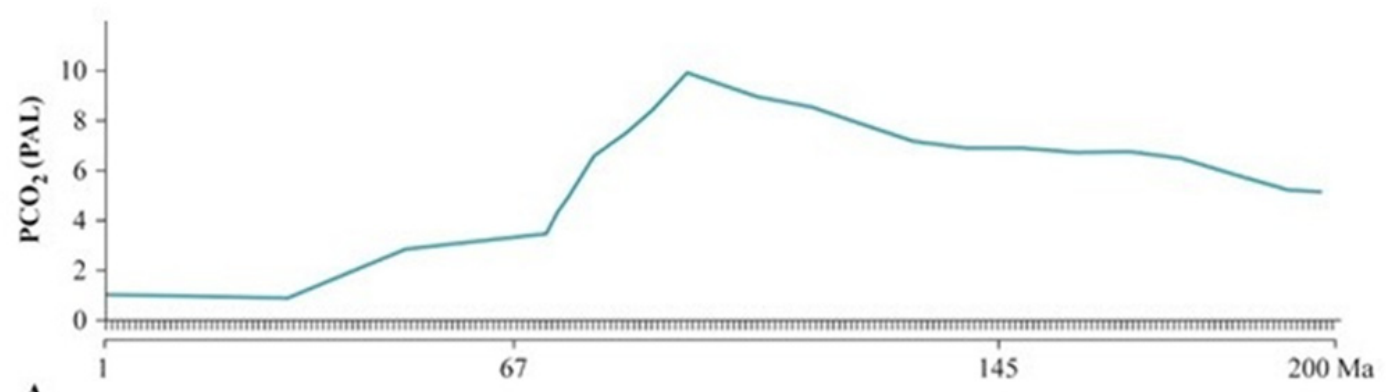

A
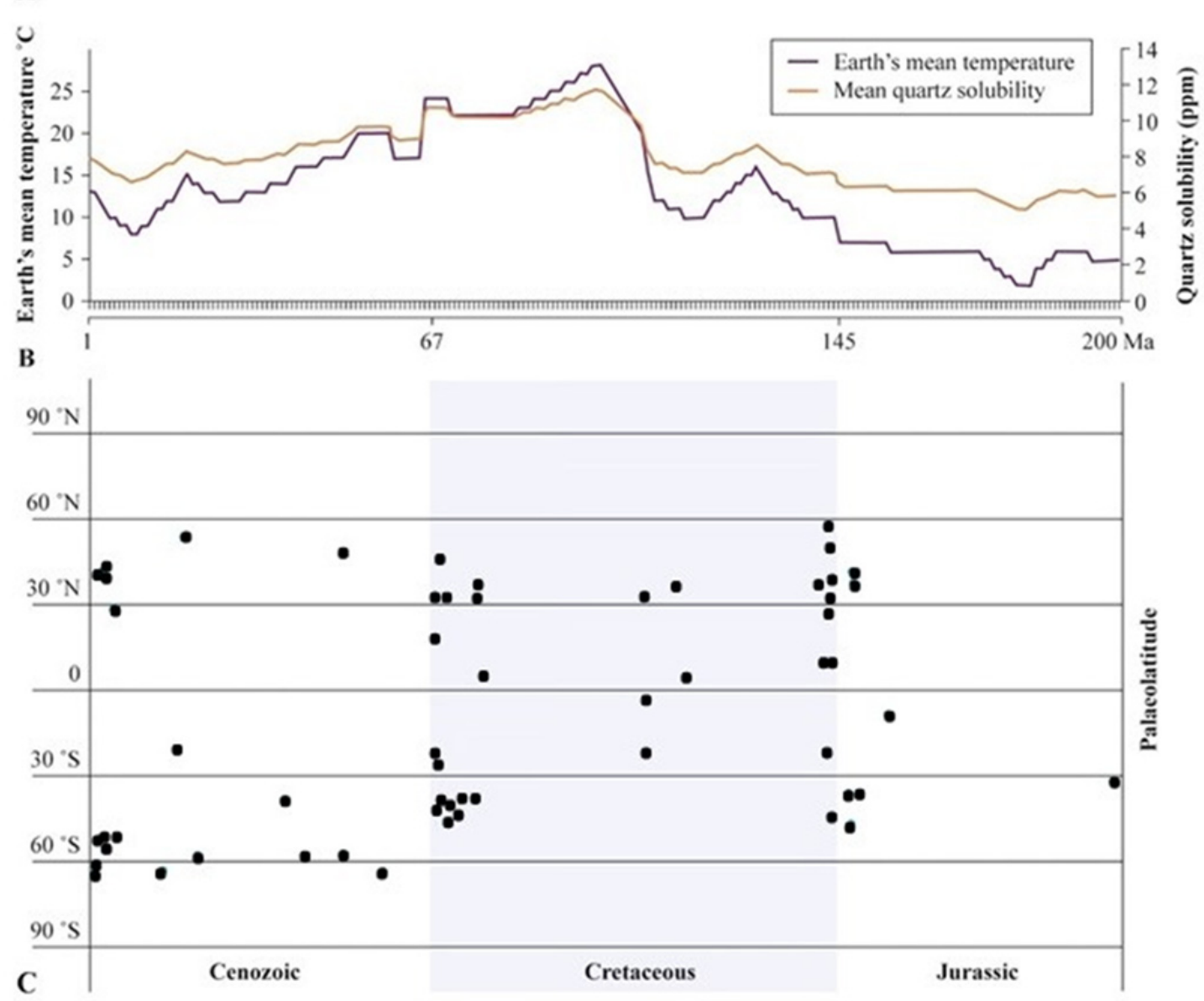

Figure 5. (A) Variation in atmospheric $\mathrm{CO}_{2}$ from the Jurassic to the present day (modified from Goddéris et al., 2014). Note the high levels of atmospheric $\mathrm{CO}_{2}$ during the Cretaceous. (B) Variation in the global mean surface temperature (modified from Veizer et al., 2000), and variation in mean global quartz solubility from the Jurassic to the present day. Note the high global mean temperature and high mean global quartz solubility during the Cretaceous. (C) Palaeolatitude distribution of silcretes from the Jurassic to the present day. Note the abundant and widespread occurrence of Cretaceous silcretes within the shaded area 

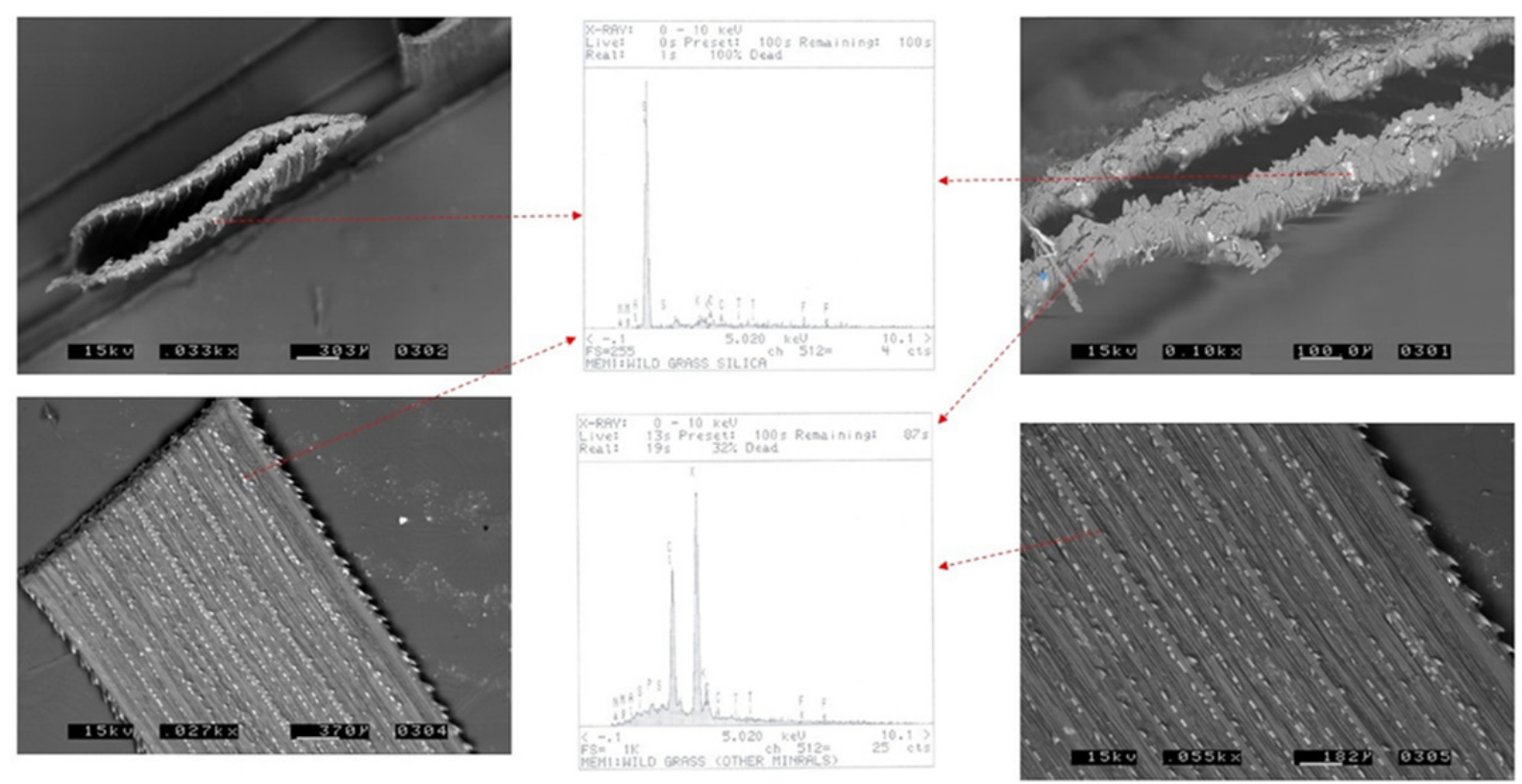

Figure 6. Scanning electron microscope (SEM) backscattered electron (BSE) images (vertical, with the internal structure exposed) and X-ray spectra of grass. Note the high abundance of silica in the results of energy dispersive X-ray analysis (EDAX). Other elements identified in the wild grass include $\mathrm{K}, \mathrm{Cl}, \mathrm{P}, \mathrm{S}$, and $\mathrm{Ca}$

\subsection{Cretaceous Origin of the Poaceae Family of Grass and the High Availability of Silica in the Cretaceous} Wild grasses of the Poaceae family are most valuable of all plant families because they occur in several of the natural and artificial landscape of the world (Bremer 2002). The grass family is also of particular interest to humans because for most of the global population grasses, including rice, wheat, and maize, constitute a major food source. Domestic animals are also raised on diets consisting partially or wholly of grass. The grass family includes about 10,000 species classified into 600-700 genera (Clayton and Renvoize, 1986; Watson and Dallwitz, 1989). The evolutionary history of grass is complex, however biogeographic studies (e.g., Bouchenak-Khelladi et al., 2010; Bremer 2002; Jassen and Bremer 2004; Kellogg, 2001) have shown that the Poaceae family evolved and diversified during the Cretaceous period. This is consistent with the works of Prasad et al. (2005) who reported the occurrence of silicified plant tissues (phytoliths) preserved in the Cretaceous Lameta Formation occurring at Pisdura, central India. In order to explore a possible connection between the origin of grass, and the high availability of silica during the Cretaceous, modern day wild grass (which also belongs to the Poaceae family of grass) was examined under the scanning electron microscope (SEM) for any evidence of silica. The results reveal the abundance of silica in the leaves of wild grass (Fig. 6). This is consistent with evidence from the biogeological record (e.g., Agarie et al 1996; Kaufman et al., 1985; Massey et al., 2006; Neethirajan et al., 2009; Nylese et al., 2015), which also illustrates the occurrence of amorphous silica gel in the shoots and leaves of wild grasses.

Grasses usually take up silica in large quantities, as it is important for their normal growth and development. When deprived of silica, grass shoots become stunted and very weak (Kaufman et al., 1985; Takahashi 1974). The silica in grass also helps to protect them against pathogenic fungi and insect herbivores (Kaufman et al., 1985; Massey et al., 2006). The high availability of silica in the Cretaceous must have played an important role in the evolution and diversification of the Poaceae family of grass. Wild grasses have short life cycles (e.g. Opanowicz et al., 2008), and when they die, they decompose with their siliceous remains added to the soil. This increases the amount of silica in soils. Clarke (2003) explained that biogenic silica produced by vascular plant constitutes about $2-3 \%$ of most soils. Some early works on silcrete (e.g. Oehler, 1979) suggested that silica sourced from the dissolution of the siliceous remains of terrestrial organisms could contribute to the formation of silcretes. Gunn and Galloway (1978) also postulated the possibility that biogenic silica leached from marine organisms was an important component in some Australian silcretes developed in the Cretaceous. This further suggests that siliceous input from decomposing Cretaceous grasses could contribute to the high availability of silica in Cretaceous soils and rock profiles and thence to the widespread development of Cretaceous silcretes.

\section{Summary and Conclusion}

The development of silcrete depends upon a complex interplay between climate and silica supply. The widespread occurrence of Cretaceous silcretes can be attributed to high levels of atmospheric $\mathrm{CO}_{2}$, extreme 
elevated global temperatures, and a high rate of deep weathering, all which prevailed during the period. It could be argued that the abundant Cretaceous silcretes identified in the geological record have resulted primarily from the extensive study of Cretaceous rocks, such that unreported occurrences of silcretes may exist in other geologic periods. Nevertheless, the dataset and discussion presented in this study show that the factors that typically control silcrete development (high atmospheric $\mathrm{CO}_{2}$, warmth, high rates of chemical weathering, and high quartz solubility) prevailed globally during the Cretaceous, which strongly supports a connection between the greenhouse climatic condition witnessed in the Cretaceous and the widespread development of silcretes. As discussed, dating silcrete development is controversial and past works have shown that very few ages of silicification are well constrained (e.g., Thiry et al., 1988). However, in this study a simple dating approach was used, and the ages of silcretes were determined from their stratigraphic position. Based on the present study, the following conclusions can be drawn.

i) Increased quartz solubility during the Cretaceous explains the widespread occurrence of Cretaceous silcretes. Silcrete occurrence is consistent with records of palaeotemperature, with the extreme global warming witnessed during the Cretaceous causing a marked increase (of $\sim 100 \%$ ) in quartz solubility, explaining the widespread occurrence of abundant Cretaceous silcretes.

ii) Mean global quartz solubility was $6 \mathrm{ppm}$ during the Jurassic, $8.14 \mathrm{ppm}$ in the Lower Cretaceous, and 10.7 ppm in the Upper Cretaceous. Mean global quartz solubility for the Cenozoic is $8.22 \mathrm{ppm}$. This again demonstrate the relatively higher availability of silica during the Cretaceous, than the Jurassic or Cenozoic

iii) Silcretes occur mainly at palaeolatitudes that experienced warm climatic conditions over time. No records of silcrete occurrence have been reported from the polar regions, where temperatures have remained low throughout geologic history.

iv) The Poaceae family of grass plants evolved and diversified in the Cretaceous, which also coincide with the period when quartz was readily available. The high availability of silica in the Cretaceous must have played an important role in the evolution and diversification of the Poaceae family of grass.

v) X-ray spectra and BSE images from SEM examination of the internal structure of a modern wild grass (which belongs to the Poaceae family of grass plants) confirms that silica is an important constituent of the Poaceae family of grass. Decomposing Cretaceous grasses must have contributed to the high availability of silica in Cretaceous soils and rock profiles which further contributed to the development of more Cretaceous silcretes.

\section{Acknowledgments}

I am thankful to the Petroleum Technology Development Fund of Nigeria (PTDF) for sponsoring my PhD research work at the University of Aberdeen. I am also grateful to the management of Abubakar Tafawa Balewa University, Bauchi, Nigeria, for permitting me to proceed on study leave. I am equally grateful to John Still for his help during laboratory work.

\section{References}

Abdel-Wahab, A., Salem, A. M., \& Mcbride, E. F. (1998). Quartz cement of meteoric origin in silcrete and nonsilcrete sandstones, Lower Carboniferous, western Sinai, Egypt. Journal of African Earth Sciences, 27, 277-290.

Agarie, S., Agata, W., Uchida, H., Kubota, F., \& Kaufman, P. B. (1996). Function of silica bodies in the epidermal system of rice (Oryza sativa L.): Testing the window hypothesis. Journal of Experimental Botany, 47, 655-660.

Akhtar, K., Khan, M. M., \& Ahmed, A. H. M. (1992). Diagenetic evolution of a Cretaceous 'quartzarenite', Narmada Rift Basin, India. Sedimentary Geology, 76, 99-109.

Alexandre, A., Basile-Doelsch, I., Sonzogni, C., Sylvestre, F., Parron, C., Meunier, J. D., \& Colin, F. (2006). Oxygen isotope analyses of fine silica grains using laser-extraction technique: Comparison with oxygen isotope data obtained from ion microprobe analyses and application to quartzite and silcrete cement investigation. Geochimica et Cosmochimica Acta, 70, 2827-2835. http://dx.doi.org/10.1016/j.gca.2006.03.003

Alexandre, A., Meunier, J., Llorens, E., Hill, S. M., \& Savin, S. M. (2004). Methodological improvement for investigating silcrete formation: Petrography, FT-IR and oxygen isotope ratio of silcrete quartz cement, Lake Eyre Basin (Australia). Chemical Geology, 211, 261-274. http://dx.doi.org/10.1016/j.chemgeo.2004.06.024

Alley, R. B., Anandakrishnan, S. \& Cuffey, K. M. (1996). Subglacial sediment transport and ice-steam behaviour. Antarctic Journal of the U.S., 31, 81-82. 
Al-Ramadan, K., Morad, S., Proust, J. N., \& Al-Aamin, I. (2005). Distribution of diagenetic alteration in siliciclastic shoreface deposits within a sequence stratigraphic framework: Evidence from the Upper Jurassic, Boulonnais, NW France. Journal of Sedimentary Research, 75, 943-959. http://dx.doi.org/10.2110/jsr.2005.072

Aubrey, W. M. (1998). A newly discovered widespread fluvial facies and unconformity marking the Upper Jurassic/Lower Cretaceous boundary, Colorado Plateau. In: Capenter, K., Chure, D. J., Kirkland, J. I. (Eds.), The Upper Jurassic Morrison Formation: An Interdisciplinary Study. Modern Geology, 22, 209-233.

Audley-Charles, M. G. (1965). Some aspects of the chemistry of Cretaceous siliceous sedimentary rocks from eastern Timor. Geochimica et Cosmochimica Acta, 29, 1175-1192.

Azmon, E., \& Kedar, Y. (1985). Lower Cretaceous silcretes-ferricrete at the northern end of the African Tethys Shoreline, Makhtesh Gadol, Israel. Sedimentary Geology, 43, 261-276.

Barron, E. J., \& Washington, W. M. (1985). Warm Cretaceous climates: High atmospheric $\mathrm{CO}_{2}$ as a plausible mechanism. In: Sundquist, E. T., Broecker, W. S. (Eds.), The Carbon Cycle and Atmospheric $\mathrm{CO}_{2}$ : Natural Variations Archaean to Present: American Geophysical Union Geophysical Monograph, 32, 546-553.

Basile-Doelsch, I., Meunier, J. D., \& Parron, C. (2005). Another continental pool in the terrestrial silicon cycle. Nature, 433, 399-402. http://dx.doi.org/10.1038/nature03217

Bata, T., Parnell, J., Samaila, N. K., Abubakar, M. B., \& Maigari, A. S. (2015). Geochemical evidence for a Cretaceous oil sand (Bima oil sand) in the Chad Basin, Nigeria. Journal of African Earth Sciences, 111, 148-155. http://dx.doi.org/10.1016/j.jafrearsci.2015.07.026

Berner, R. A. (1992). Weathering, plants, and the long-term carbon cycle: Geochimica et Cosmochimica Acta, 56, 3225-3231.

Berner, R.A., 1991. A model for atmospheric CO2 over Phanerozoic time. American Journal of Science, 291, 339-376.

Birkeland, P. W. (1974). Pedology, Weathering and Geomorphological Research. New York: Oxford University Press.

Blakey, R. C. (2011). Global palaeogeography. Retrieved from http://jan.ucc.nau.edu/ rcb7/globaltext2.html

Blanco, J. A., Armenteros, I., \& Huerta P. (2008). Silcrete and alunite genesis in alluvial palaeosols (Late Cretaceous to Early Paleocene, Duero Basin, Spain). Sedimentary Geology, 211, 1-11.

Bland, W., \& Rolls, D. (1998). Weathering: An Introduction to the Scientific Principles. New York: Oxford University Press.

Bordy, E. M., \& Catuneanu, O. (2002). Sedimentology and palaeontology of upper Karoo aeolian strata (Early Jurassic) in the Tuli Basin, South Africa. Journal of African Earth Sciences, 35, 301-314. http://dx.doi.org/10.1016/S0899-5362(02)00103-3

Borger, H., McFarlane, M. J., \& Ringrose, S. (2004). Processes of silicate karstification associated with Pan Formation in the Darwin-Kopinya area of northern Australia. Earth Surface Process and Landforms, 29, 359-371.

Bouchenak - Khelladi, Y., Verboom, G. A., Savolainen, V., \& Hodkinson, T. R. (2010). Biogeography of the grasses (Poaceae): a phylogenetic approach to reveal evolutionary history in geographical space and geological time. Botanical Journal of the Linnean Society, 162, 543-557. http://dx.doi.org/10.1111/j.1095-8339.2010.01041.x

Bremer K. (2002). Gondwanan evolution of the grass alliance of families (Poales). Evolution, 56, 1374-1387. http://dx.doi.org/10.1111/j.0014-3820.2002.tb01451.x

Bustillo, M. A., \& Bustillo, M. (2000). Miocene silcretes in argillaceous playa deposits, Madrid Basin, Spain: petrological and geochemical features. Sedimentology, 47, 1023-1037. http://dx.doi.org/10.1046/j.1365-3091.2000.00337.x

Canals, M., \& Meunier, J. D. (1995). A model for porosity reduction in quartzite reservoirs by quartz cementation. Geochimica Cosmochimica Acta, 59, 699-709.

Carey, A. E., Lyons, W. B., \& Owen, J. S. (2005). Significance of landscape age, uplift, and weathering rates to ecosystem development. Aquatic Geochemistry, 11, 215-239. http://dx.doi.org/10.1007/s10498-004-5733-6

Chadwick, O. A., Hendricks, D. M., \& Nettleton, W. D. (1989). Silicification of Holocene soils in Northern 
Monitor Valley, Nevada. Soil Science Society of America Journal, 53, 158-164.

Clarke, J. (2003). The occurrence and significance of biogenic opal in the regolith. Earth Science Reviews, 60, 175-194. http://dx.doi.org/10.1016/S0012-8252(02)00092-2

Clayton W. D., \& Renvoize S. A. (1986). Genera Graminum. London: Her Majesty's Stationery Office

De Wit, M. C. J., 1999. Post Gondwana drainage and the development of diamond placers in west Southern Africa. Economic Geology, 94, 721-740.

Dinis, J. L., Rey, J. Cunha, P. P. Callapez, P., \& Pena dos Reis, R., (2008). Stratigraphy and allogenic controls of the western Portugal Cretaceous: An updated synthesis. Cretaceous Research, 29, 772-780. http://dx.doi.org/10.1016/j.cretres.2008.05.027

Dove, P. M., \& Rimstidt, J. D. (1994). Silica-water interactions. In: Heaney, P. J., Prewitt, C. T. and Gibbs, G. V. (Eds.), Silica: Physical Behaviour, Geochemistry and Materials Applications. Reviews in Mineralogy 29. Washington: Mineralogical Society of America, 259-308.

Du Toit, A. L., \& Reed, F. R. C. (1954). The Geology of South Africa. Edinburgh: Oliver and Boyd Publication.

El-Sayed, M. I. (2000). Karstic features associated with unconformity surfaces, a case study from the United Arab Emirates. Journal of Arid Environments, 46, 295-312. http://dx.doi.org/10.1006/jare.2000.0669

Firman, J. B. (1994). Paleosols in laterite and silcrete profiles: evidence from the South-east margin of the Australian Precambrian Shield. Earth-Science Reviews, 36, 149-179.

Flörke, O. W., Flörke, U., \& Giese, U. (1984). Moganite: a new microcrystalline silica-mineral. Neues Jahrbuch für Mineralogie, Abhandlungen, 149, 325-226.

Flörke, O. W., Graetsch, B., Martin, B., Röller, K., \& Wirth, R. (1991). Nomenclature of micro- and non-crystalline silica minerals, based on structure and microstructure. Neues Jahrbuch für Mineralogie, Abhandlungen, 163, 19-42.

Frankel J. J., \& Kent L. E. (1938). Grahamstown surface quartzites (silcretes). Transactions of the Geological Society of South Africa, 15, 1-42.

Friedrich, O., Norris, R.D., \& Erbacher, J., 2012. Evolution of middle to Late Cretaceous oceans-A 55 my record of Earth's temperature and carbon cycle. Geology 40, 107-110

Gassaway, J. S. (1989). Utility of San Juan Basin silcrete. American Association of Petroleum Geologist Bulletin, 73, 1156-1157.

Glen, R. A., \& Hutton, J. T. (1983). Silcretes in the Cobar area, New South Wales. Journal and Proceedings of the Royal Society of New South Wales, 116, 17-23.

Goddéris, Y., Donnadieu, Y., Le Hir, G., Lefebvre, V., \& Nardin, E. (2014). The role of palaeogeography in the Phanerozoic history of atmospheric $\mathrm{CO}_{2}$ and Climate. Earth-Science Reviews, 128, 122-138. http://dx.doi.org/10.1016/j.earscirev.2013.11.004

Golonka, J. (2007). Late Triassic and Early Jurassic palaeogeography of the world. Palaeogeography, Palaeoclimatology, Palaeoecology, 244, 297-307. http://dx.doi.org/10.1016/j.palaeo.2006.06.041

Goudie, A. S. (1973). Duricrusts in Tropical and Subtropical Landscapes. Oxford: Clarendon Press.

Goudie, A. S., \& Middleton N. J. (2001). Saharan dust storms: nature and consequences. Earth-Science Reviews, 56, 179-204. http://dx.doi.org/10.1016/S0012-8252(01)00067-8

Goudie, A. S., \& Viles, H. A. (2012). Weathering and the global carbon cycle: Geomorphological perspectives. Earth-Science Reviews 113, 59 - 71. http://dx.doi.org/10.1016/j.earscirev.2012.03.005

Graham, C. M., Valley, J. W., \& Winter, B. L. (1996). Ion microprobe analysis of 18O/16O in authigenic and detrital quartz in the St. Peter Sandstone, Michigan Basin and Wisconsin Arch, USA: contrasting diagenetic histories. Geochimica Cosmochimica Acta, 60, 5101-5116.

Gunn, R.H., \& Galloway, R.W. (1978). Silcretes in south-central Queensland. In: Langford-Smith, (Ed.), Silcrete in Australia. Department of Geography, University of New England, Armidale, pp. 51-71.

Hallam, A. (1984). Continental humid and arid zones during the Jurassic and Cretaceous. Palaeogeography, Palaeoclimatology, Palaeoecology, 47, 195-223.

Hancock, J. M. (2000). The Griban Formation: Clues to the latest Cretaceous history of western Scotland. Scottish Journal of Geology, 36, 137-141. http://dx.doi.org/10.1144/sjg36020137 
Haq, B. U. \& Schutter, S. R. (2008). A chronology of Paleozoic sea-level changes. Science, 322, 64-68. http://dx.doi.org/10.1126/science.1161648

Huber, B.T., Hodell, D.A., \& Hamilton, C.P. (1995). Middle-Late Cretaceous climate of the southern high latitudes: stable isotopic evidence for minimal equator-to-pole thermal gradients. Geological Society of America Bulletin 107, 1164-1191.

Huber, B.T., Norris, R.D., \& MacLeod, K.G. (2002). Deep-sea paleotemperature record of extreme warmth during the Cretaceous. Geology 38, 123-126. http://dx.doi.org/10.1130/0091-7613(2002) $030<0123$ :DSPROE $>2.0 . \mathrm{CO} ; 2$

Hutton, J. T., Twidale, C. R., \& Milnes, A. R. (1978). Characteristics and origin of some Australian silcretes. In: Langford-Smith, T. (Ed.) Silcrete in Australia. Armidale: University of New England Press, pp. 19-39.

Hutton, J. T., Twidale, C. R., Milnes, A. R., \& Rosser, H. (1972). Composition and genesis of silcretes and silcrete skins from the Beda valley, southern Arcoona plateau, South Australia. Journal of the Geological Society of Australia, 19, 31-39.

Idnurm, M., \& Senior, B. R. (1977). Paleomagnetic ages of Late Cretaceous and Tertiary weathered profiles in the Eromanga Basin, Queensland. Palaeogeography, Paleoclimatology, Palaeoecology, 24, $263-277$.

Jacob, R. E., Mitha, V. R., \& Macpherson, D. (2004). The kaolinitic clay deposits of Beaconsfield, north of Grahamstown. South African. Journal of Science, 100, 560-563.

Janssen, T., \& Bremer, K. (2004). The age of major monocot groups inferred from 800+ rbcL sequences. Botanical Journal of the Linnean Society, 146, 385-398. http://dx.doi.org/10.1111/j.1095-8339.2004.00345.x

Kaufman, P. B., Dayanandan, P., Franklin, C. I., \& Takeoka, Y. (1985). Structure and function of silica bodies in the epidermal system of grass shoots. Annals of Botany, 55, 487-507.

Kellogg, E. A. (2001). Evolutionary history of the grasses. Plant physiology, 125, 1198-1205. http://dx.doi.org/10.1104/pp.125.3.1198

Kemp, E. M. (1978). Tertiary climate evolution and vegetation history in the southeast Indian Ocean region. Palaeogeography, Palaeoclimatology, Palaeoeeology, 24, 169-208.

Khalaf, F. I. (1988). Petrography and diagenesis of silcrete from Kuwait, Arabian Gulf. Journal of Sedimentary Research, 58, 1014-1022.

Knauth, L. P. (1994). Petrogenesis of chert. In: Heaney, P. J., Prewitt, C. T., and Gibbs, G. V. (Eds.), Silica: Physical Behaviour, Geochemistry and Materials Applications. Reviews in Mineralogy 29. Washington: Mineralogical Society of America, pp. 233-258.

Krause, F. F., \& Mellor, A. F. (2010). Pedogenic and groundwater silcretes in paleovalleys filling J3 and J2 Sandstones, Medicine River area, west-central Alberta, Canada. GeoCanada-2010-Working with the Earth. Retrieved from http://cseg.ca/assets/files/resources/abstracts/2010/core/0659_GC2010_Pedogenic_and_Groundwater_Silcr etes.pdf

Kump, L. R., Pavlov, A., \& Arthur, M. A. (2005). Massive release of hydrogen sulfide to the surface ocean and atmosphere during intervals of oceanic anoxia: Geology, 33, 397-400. http://dx.doi.org/10.1130/G21295.1

Laity, J. (2009). Desert and Desert Environments. West Sussex, UK: Blackwell Publishing.

Larson, R. L. (1991). Geological consequences of superplumes. Geology, 19, 963-966.

Leckie, D. A., \& Cheel, R. J. (1990). Nodular silcretes of the Cypress Hill Formation (upper Eocene to middle Miocene) of southern Saskatchewan, Canada. Sedimentology, 37, 445-454.

Lindsay, W. L. (1979). Chemical Equilibria in Soils. New York: John Wiley.

Massey, F. P., Ennos, A. R., \& Hartley, S. E. (2006). Silica in grasses as a defence against insect herbivores: contrasting effects on folivores and a phloem feeder. Journal of Animal Ecology, 75, 595-603. http://dx.doi.org/10.1111/j.1365-2656.2006.01082.x

McArthur, J. M., Turner, J. V., Lyons, W. B., Osborn, A. O., \& Thirlwall, M. F. (1991). Hydrochemistry on the Yilgarn Block, Western Australia: ferrolysis and mineralization in acidic brines. Geochimica et Cosmochimica Acta, 55, 1273-1288. 
McCarthy, T. S., \& Ellery, W. N. (1995). Sedimentation on the distal reaches of the Okavango Fan, Botswana, and its bearing on calcrete and silcrete (gannister) formation. Journal of Sedimentary Research, 65, 77-90.

Meesook, A. (2000). Cretaceous environment of north-eastern Thailand. Developments in Paleontology and Stratigraphy, 17, 207-223.

Miller, K. G., Kominz, M. A., Browning, J. V., Wright, J. D., Mountain, G. S., Katz, M. E., \& Pekar, S. F. (2005). The Phanerozoic record of global sea-level change. Science, 310, 1293-1298. http://dx.doi.org/10.1126/science.1116412

Millot, G. (1960). Silice, silex, silicifications et croissance des cristaux. Bulletin de Service Carte Geologique, Alsace Lorraine, 13, 129-146.

Millot, G., 1970. Geology of Clays: Weathering, Sedimentology, Geochemistry (translated by Farrand, W. R.and Paquet, H.). New York: Springer-Verlag.

Milnes, A. R., \& Twidale, C. R. (1983). An overview of silicification in Cainozoic landscapes of arid central and southern Australia. Australian Journal of Soil Research, 21, 387-410.

Milnes, A. R., Thiry, M. (1992). Silcretes. In: Martini, I. P. and Chesworth, W. (Eds.), Weathering, Soils and Palaeosols. Developments in Earth Surface Processes 2. Amsterdam: Elsevier, pp. 349-377.

Milnes, A. R., Wright, M. J., \& Thiry, M. (1991). Silica accumulations in saprolites and soils in South Australia. In: Nettleton, W. D. (Ed.) Occurrence, Characteristics and Genesis of Carbonate, Gypsum, and Silica Accumulations in Soils. Madison, WI: Soil Science Society of America, Special Publication 26, 121-149.

Mis `́k M. M. (1996). Silica spherulites and fossil silcretes in carbonate rocks of western Carpathians. Geologica Carpathica Clays, 47, 91-105.

Moore, D. B., \& Henderson, C. M. (1998). The Pennsylvanian to Permian Belloy Formation in the Peace River Embayment, West Central Alberta. Extended Abstract Geo-triad' 98: Abstract, plenary, oral, posters, core workshop, 511-514. Retrieved from http://archives.datapages.com/data/cspg_sp/data/CSPG-S022/022001/511_cspgsp220511.htm

Murray R. C., 1990. Diagenetic silica stratification on a paleosilcrete, North Texas. Journal of Sedimentary Research, 6, 717-720.

Mutti, M. (1995). Porosity development and diagenesis in Orfento super sequence and its bounding unconformities (Upper Cretaceous) Montagna della Maiella, Italy. In: Budd, D. A., Saller, A. H., Haris, P. M. (Eds.), Unconformities and Porosity in Carbonate Strata. American Association of Petroleum Geologist Memoir 63.

Nash, D. J., \& Hopkinson, L. (2004). A reconnaissance Laser Raman and Fourier Transform Infrared survey of silcretes from the Kalahari Desert, Botswana. Earth Surface Processes and Landforms, 29, 1541-1558. http://dx.doi.org/10.1002/esp.1137

Nash, D. J., \& Shaw, P. A. (1998). Silica and carbonate relationships in silcretes-calcrete intergrade duricrusts from the Kalahari Desert of Botswana and Namibia. Journal of African Earth Science, 27, 11-25.

Nash, D. J., \& Ullyott J. S. (2007). Silcretes in: Nash, D. J., McLaren S. J., 2007. Geochemical Sediments and Landscapes. Malden, USA: Blackwell Publishing Ltd.

Nash, D. J., Thomas, D. S. G., \& Shaw, P. A. (1994). Siliceous duricrusts as palaeoclimatic indicators: Evidence from the Kalahari Desert of Botswana. Palaeogeography, Palaeoclimatology, Palaeoecology, 112, 279 295.

Neethirajan, S., Gordon, R., \& Wang, L. (2009). Potential of silica bodies (phytoliths) for nanotechnology. Trends in Biotechnology, 27, 461-467.

Nikinmaa, M. (2013). Climate change and ocean acidification-Interactions with aquatic toxicology. Aquatic Toxicology, 126, 365-372.

Nylese, T. L., Berry, A., \& Oscher, S. (2015). Elemental Analysis of Silicon in Plant Material with Variable-Pressure SEM. Microscopy Today, 23, 26-31.

Oehler, J.H. (1979). Deposition and diagenesis of biogenic silica. In: Trudinger, P.A., Swain, D.J. (Eds.), The Biogeochemical Cycling of Mineral-Forming Elements. Elsevier, Amsterdam, pp. 467-479

Opanowicz, M., Vain, P., Draper, J., Parker, D., \& Doonan, J. H. (2008). Brachypodium distachyon: making hay with a wild grass. Trends in plant science, 13, 172-177. http://dx.doi.org/10.1016/j.tplants.2008.01.007 
Parnell, J. (1983). Ancient duricrusts and related rocks in perspective: a contribution from the Old Red Sandstone. Geological Society, London, Special Publications 11, 197-209.

Peters, S. E., \& Gaines, R. R. (2012). Formation of the Great Unconformity as a trigger for the Cambrian explosion. Nature, 484, 363-366. http://dx.doi.org/10.1038/nature10969

Pierini, C., Mizusaki, A. M., Pimental, N., Faccini, U. F., \& Scherer, C. M. S. (2010). Palaeoweathering features in the Sergi Formation (Jurassic-Cretaceous), northeastern Brazil and implication for hydrocarbon exploration. Journal of South American Earth Science, 29, 412-426. http://dx.doi.org/10.1016/j.jsames.2009.04.002

Prasad, V., Strömberg, C. A., Alimohammadian, H., \& Sahni, A. (2005). Dinosaur coprolites and the early evolution of grasses and grazers. Science, 310, 1177-1180. http://dx.doi.org/10.1126/science.1118806

Putnam, P. E., Kendall, G., \& Winter, D. A. (1997). Estuarine deposit of the Upper Qishn Formation (Lower Cretaceous) Masila region, Yemen. American Association of Petroleum Geologist Bulletin, 81, 1306-1329.

Radtke, U., \& Brückner, H. (1991). Investigations on age and genesis of silcretes in Queensland (Australia) preliminary results. Earth Surface Processes and Landforms, 16, 547-554.

Retallack, G. J. (2001). A 300-million-year record of atmospheric CO2 from fossil plant cuticles. Nature, 411, 287-290. http://dx.doi.org/10.1038/35077041

Rimstidt, D. J. (1997). Quartz solubility at low temperatures. Geochimica et Cosmochimica Acta, 61, 25532558.

Ross, G. M., \& Chiarenzelli, J. R. (1985). Paleoclimatic significance of widespread Proterozoic silcretes in the Bear and Churchill provinces of the north-western Canadian Shield. Journal of Sedimentary Petrology, 55, 196-204.

Royer, D. L. (2008). Linkages between CO2, climate, and evolution in deep time. Proceedings of the National Academy of Sciences, 105, 407-408. http://dx.doi.org/10.1073/pnas.0710915105

Royer, D. L. (2010). Fossil soils constrain ancient climate sensitivity. Proceedings of the National Academy of Sciences, 107, 517-518. http://dx.doi.org/10.1073/pnas.0913188107

Royer, D. L., Berner, R. A., Montañez, I. P., Tabor, N. J., \& Beerling, D. J., 2004. $\mathrm{CO}_{2}$ as a primary driver of Phanerozoic climate. GSA Today, 14, 4-10. http://dx.doi.org/10.1130/1052-5173(2004)0142.0.CO;2

Scherer, C. M. S., \& Lavina, E. L. C. (2006). Stratigraphic evolution of a fluvial-eolian succession: The example of the Upper Jurassic-Lower Cretaceous Guara and Botucata Formations, Parana Basin, Southmost Brazil. Gondwana Research, 9, 475-484. http://dx.doi.org/10.1016/j.gr.2005.12.002

Schubel, K. A., \& Simonson, B. M. (1990). Petrography of cherts from Lake Magadi, Kenya. Journal of Sedimentary Petrology, 60, 761-776.

Scotese, C. R. (2001). Atlas of Earth History. Palaeogeography, PALEOMAP Project, Arlington, Texas, Volume 1, 52.

Sempéré, T., Butler, R. F., Richards, D. R., Marshall, L. G., Sharp, W., \& Swisher Iii, C. C. (1997). Stratigraphy and chronology of Upper Cretaceous-lower Paleogene strata in Bolivia and northwest Argentina. $\begin{array}{llllll}\text { Geological Society of } & \text { America }\end{array}$ http://dx.doi.org/10.1130/0016-7606(1997)109<0709:SACOUC $>2.3 . C O ; 2$

Shaw, P. A., Cooke, H. J., \& Perry, C. C. (1990). Microbialitic silcretes in highly alkaline environments: some observations from Sua Pan, Botswana. South African Journal of Geology, 93, 803-808.

Skarpelis, N. (2006). Lateritization processes of ultra-mafic rocks in Cretaceous times: The fossil weathering crust of Mainland Greece. Journal of Geochemical Exploration, 88, 325-328. http://dx.doi.org/10.1016/j.gexplo.2005.08.066

Skelton, P. W. (2003). The Cretaceous World. London: Cambridge University Press.

Smale, D. (1973). Silcretes and associated silica diagenesis in southern Africa and Australia. Journal of Sedimentary Petrology, 43, 1077-1089.

Smith, G. L., Dott, Jr, R. H., \& Byers, C. W. (1997). Authigenic silica fabrics associated with Cambro-Ordovician unconformities in the Upper Midwest. Geoscience Wisconsin, 16, 25-36.

Stephens, C. G., 1971. Laterite and silcrete in Australia: a study of the genetic relationships of laterite and 
silcrete and their companion materials, and their collective significance in the formation of the weathered mantle, soils, relief and drainage of the Australian continent. Geoderma, 5, 5-52.

Summerfield, M. A. (1981). The nature and occurrence of silcrete, Southern Cape Province, South Africa. School of Geography Research Paper 28, University of Oxford.

Summerfield, M. A. (1983)a. Geochemistry of weathering profile silcretes, southern Cape Province, South Africa. In: Wilson, R. C. L. (Ed.) Residual Deposits: Surface Related Weathering Processes and Materials. Geological Society of London, Special Publication 11, 167-178.

Summerfield, M. A. (1983)b. Silcretes as a palaeoclimatic indicator: Evidence from South Africa. Palaeogeography, Palaeoclimatology, Palaeoecology, 41, 65-79.

Swoboda-Colberg, N. G., \& Drever, J. I., (1993). Mineral dissolution rates in plot-scale field and laboratory experiments. Chemical Geology, 105, 51-69.

Takahashi, E. (1974). Comparative Plant Nutrition. Tokyo: Yokendo Publishers.

Taylor, G., \& Eggleton, R. A. (2001). Regolith Geology and Geomorphology. Chichester: John Wiley.

Terry, D. O., \& Evans, J. E. (1994). Pedogenesis and paleoclimatic implications of the Chamberlain Pass Formation, Basal White River Group, Badlands of South-Dakota. Palaeogeography, Palaeoclimatology, Palaeoecology, 110, 197-215.

Terry, R. C., Rogers, R. R., \& Wirth, K. R. (2001). Character and origin of the Mpandi silcretes (Early Jurassic?), Limpolo Valley, Zimbabwe. Book of Abstract, Geological Society of America, 33, 446.

Thiry, M. (1978). Silicification des sédiments sablo-argileux de l'Yprésien du sudest du bassin de Paris. Genèse et évolution des dalles quartitiques et silcrètes. Bulletin du B.R.G.M. (deuxième serie), 1, 19-46.

Thiry, M. (1999). Diversity of continental silicification features: examples from the Cenozoic deposits in the Paris Basin and neighbouring basement. In: Thiry, M., and Simon-Coinçon, R. (Eds.), Palaeoweathering, Palaeosurfaces and Related Continental Deposits. International Association of Sedimentologists. Oxford: Blackwell Science, Special Publication 27, 87-127.

Thiry, M., \& Millot, G. (1987). Mineralogical forms of silica and their sequence of formation in silcretes. Journal of Sedimentary Petrology, 57, 343-352.

Thiry, M., \& Milnes, A. R. (1991). Pedogenic and groundwater silcretes at Stuart Creek opal field, South Australia. Journal of Sedimentary Petrology 61, 111-127.

Thiry, M., \& Simon-Coincon, R. (1996). Tertiary palaeoweathering and silcretes in Southern Paris Basin. Catena, 26, 1-26.

Thiry, M., Bertrand-Ayrault, M., \& Grisoni, J. C. (1988). Ground-water silicification and leaching in sands: example of the Fontainebleau Sand (Oligocene) in the Paris Basin. Bulletin of the Geological Society of America, 100, 1283-1290.

Thiry, M., Milnes, A. R., Rayot, V., \& Simon-Coinçon, R. (2006). Interpretation of palaeoweathering features and successive silicifications in the Tertiary regolith of inland Australia. Journal of the Geological Society, 163, 723-736. http://dx.doi.org/10.1144/0014-764905-020

Thiry, M., Schmitt, J.M., Rayot, V. \& Milnes, A.R. (1995) Geochemistry of the bleached profiles of the Tertiary regolith of inland Australia. Comptes Rendus de l'Academie des Sciences Series II 320, 279-285.

Tofalo, O. R., \& Pazos, P. J. (2010). Paleoclimatic implications (late Cretaceous-Paleogene) from micromorphology of calcretes, plustrine limestone and silcretes southern Parana Basin, Uruguay. Journal of South American Earth Sciences, 29, 665-675.

Twidale, C. R. (2007). Ancient Australian landscapes. New South Wales: Rosenberg Publishing Co.

Twidale, C. R., \& Campbell, E. M. (1995). Pre-Quaternary landforms in the low latitude context: The example of Australia. Geomorphology, 12, 17-35.

Twidale, C. R., \& Hutton, J. T. (1986). Silcrete as a palaeoclimatic indicator: Discussion. Palaeogeography, Palaeoclimatology, Palaeoecology, 52, 351-356.

Twidale, C. R., Bourne, J. A., \& Smith, I. M. (1976). Age and origin of palaeosurfaees on Eyre Peninsula and in the southern Gawler Ranges, South Australia. Z. Geomorphology, 20, 28-55.

Ullyott, J. S., \& Nash, D. J. (2006). Micromorphology and geochemistry of ground water silcrete boulders in the 
eastern south Dawns, UK. Sedimentology, 53, 387-412. http://dx.doi.org/10.1111/j.1365-3091.2005.00762.x

Ullyott, J. S., Nash, D. J., \& Shaw, P. A. (1998). Recent advances in silcrete research and their implications for the origin and palaeoenvironmental significance of sarsens. Proceedings of the Geologists' Association, 109, 255-270. http://dx.doi.org/10.1016/S0016-7878(98)80019-9

Ullyott, J. S., Nash, D. J., Whiteman, C. A., \& Mortimore, R. (2004). Distribution, petrology and mode of development of silcretes (sarsens and puddingstones) on the eastern South Downs, UK. Earth Surface Processes and Landforms, 29, 1509-1539. http://dx.doi.org/10.1002/esp.1136

Valeton, I., Biermann, M., Reche, R., \& Rosenberg, F. (1987). Genesis of nickel laterites and bauxites in Greece during the Jurassic and Cretaceous and their relationship to ultrabasic parent rocks. Ore Geology Review, 2, 359-404.

Veizer, J., Godderis, Y., \& François, L. M. (2000). Evidence for decoupling of atmospheric $\mathrm{CO}_{2}$ and global climate during the Phanerozoic eon. Nature, 408, 698-701.

Wang, Y., Huang, C., Sun, B., Quan, C., Wu, J., \& Lin, Z. (2014). Paleo- $\mathrm{CO}_{2}$ variation trends and the Cretaceous $\begin{array}{lllll}\text { greenhouse } \quad \text { climate. } & \text { Earth-Science }\end{array}$ http://dx.doi.org/10.1016/j.earscirev.2013.11.001

Watchman, A. L., \& Twidale, C. R. (2002). Relative and 'absolute' dating of land surfaces. Earth-Science Reviews, 58, 1-49. http://dx.doi.org/10.1016/S0012-8252(01)00080-0

Watson L., \& Dallwitz M. J. (1989). Grass genera of the world: interactive identification and information retrieval. Version 1.0. Flora Online 22. Retrieved from http://www.motbot.org/plantscience/ResBot/FO/FloraOnline.htm

Watson L., \& Dallwitz M. J. (1999). Grass genera of the world: descriptions, illustrations, identification, and information retrieval, including synonyms, morphology, anatomy, physiology, phytochemistry, cytology, classification, pathogens, world and local distribution, and references. Retrieved from $\mathrm{http} / / /$ biodiversityunoedu/delta/Version (August 18, 1999)

Webb, J. A., \& Golding, S. D. (1998). Geochemical mass-balance and oxygen-isotope constraints on silcrete formation and its palaeoclimatic implications in southern Australia. Journal of Sedimentary Research, 68, 981-993.

Williams, L. A., Parks, G. A., \& Crerar, D. A. (1985). Silica diagenesis, I. Solubility controls. Journal of Sedimentary Petrology, 55, 301-311.

Wopfner, H. (1978). Silcretes of northern-south Australia and adjacent regions. In: Langford-Smith, T. (Ed.), Silcretes in Australia. Department of Geography, University of Armidale, N.S.W. 73-141.

Wopfner, H. (1983). Environment of silcrete formation: a comparison of examples from Australia and the Cologne Embayment, West Germany. In: Wilson, R. C. L. (Ed.), Residual Deposits: Surface Related Weathering Processes and Materials. Geological Society of London, Special Publication, 11, 151-157.

\section{Copyrights}

Copyright for this article is retained by the author(s), with first publication rights granted to the journal.

This is an open-access article distributed under the terms and conditions of the Creative Commons Attribution license (http://creativecommons.org/licenses/by/3.0/). 